Helle B. Hager (f. 1969) er spesialist i medisinsk biokjemi og avdelingsoverlege ved Sentrallaboratoriet, Sykehuset i Vestfold.

Forfatter har fylt ut ICMJE-skjemaet og oppgir ingen interessekonflikter.

Litteratur

1. Aakre KM, Hov GG, Skadberg $\emptyset$. Varsling av sterkt avvikende analyseresultater til rekvirenter utenfor sykehus. Tidsskr Nor Legeforen 2013; e-publisert 12.11.2013.

2. Burtis C, Ashwood E, Bruns D. Tietz textbook of clinical chemistry and molecular diagnostics. 5. utg. Philadelphia, PA: Elsevier, 2012.

3. Howanitz PJ, Steindel SJ, Heard NV. Laboratory critical values policies and procedures: a college of American Pathologists Q-Probes Study in 623 institutions. Arch Pathol Lab Med 2002; 126 : $663-9$.

4. Tillman J, Barth JH. A survey of laboratory 'critical lalert) limits' in the UK. Ann Clin Biochem 2003; 40: $181-4$.
Mottatt 2.8. 2013, første revisjon innsendt 28.8. 2013, godkjent 14.10. 2013. Redaktør Trine B. Haugen.

Publisert først på nett.

\title{
Nye anbefalinger for tolking av troponinverdier
}

\author{
For å sikre enhetlig diagnostikk har de store internasjonale kardiologiorganisasjonene publisert diagnostiske \\ definisjoner for tilstanden akutt hjerteinfarkt, sist i 2012. En arbeidsgruppe sammensatt av laboratorieleger \\ og kardiologer har gitt en anbefaling for hvordan denne bør implementeres i Norge. En konsekvens er at den \\ diagnostiske beslutningsgrensen for hjerteinfarkt senkes til 99-prosentilen for alle troponinmetodene.
}

En undersøkelse gjennomført i 2009 viste at det ved norske sykehus ble benyttet svært mange ulike beslutningsgrenser for troponiner ved diagnostikk av akutt hjerteinfarkt (AMI) (1). På bakgrunn av dette ble det i 2009 gitt en nasjonal anbefaling vedrørende infarktdiagnostikk (1). Etter at The third universal definition of mycardial infarction ble publisert av European Society of Cardiology/American College of Cardiology Foundation/American Heart Association/The World Heart Federation i 2012 (2), har en arbeidsgruppe nedsatt av Norsk Selskap for Medisinsk Biokjemi og Norsk Cardiologisk Selskap utarbeidet en oppdatert nasjonal anbefaling for diagnostikk av akutt hjerteinfarkt. Retningslinjene er tilgjengelig i fulltekst i nettutgaven av Tidsskriftet (3).

For å stille diagnosen akutt hjerteinfarkt skal det foreligge en troponinmåling over 99-prosentilen samt en signifikant endring i troponinkonsentrasjon etter 6 timers observasjon sammenliknet med innkomst. Signifikant endring kan ofte ses etter kortere observasjon, og ved uklar symptomatologi kan lengre observasjon være nødvendig for å utelukke sykdom. I tillegg skal det foreligge et relevant klinisk bilde og/eller bildediagnostiske funn. De største forskjellene mellom anbefalingene i 2013 og 2009 er at diagnostisk beslutningsgrense for hjerteinfarkt senkes til 99-prosentilen for alle troponinmetodene, og at det angis hva som er en signifikant endring, forutsatt bruk av høysensitive troponinmetoder. I tillegg foreslås en kortere observasjonstid.

\section{Troponin - beslutningsgrenser og endring i konsentrasjon} Som beslutningsgrenser for akutt hjerteinfarkt anbefaler arbeidsgruppen bruk av 99prosentiler som er funnet i en presumtivt hjertefrisk populasjon. I tråd med internasjonale anbefalinger (2) er det angitt kun én verdi per metode selv om 99-prosentilen kan variere med bl.a. kjønn og alder (tab 1). Bruk av én verdi vil trolig lette implementeringen, og arbeidsgruppen mener det per i dag ikke er tilstrekkelig dokumentasjon for å anbefale kjønns- og aldersstratifisering.

\section{«Diagnostisk beslut- ningsgrense for hjerte- infarkt senkes til 99-prosentilen for alle troponinmetodene»}

Det er likevel viktig å være klar over at kvinnelige pasienter med relevante kliniske funn som har troponinendringer over $50 \%$ uten å overstige den felles angitte 99-prosentilen, kan ha verdier som overstiger 99-prosentilen for kvinner (tab 1, fotnote). Disse må derfor observeres med særskilt aktsomhet.

Mange pasienter har stabile troponinverdier over 99-prosentilen uten at de har iskemisk hjertesykdom. For å øke spesifisiteten skal det derfor i tillegg til en troponinverdi over 99-prosentilen også påvises signifikant stigning eller fall i troponinkonsentrasjoner i løpet av et gitt tidsrom. I konsensusdokumentet fra de store kardiologiorganisasjonene er ikke størrelsen på en signifikant endring kvantifisert (2). Dette medfører at troponinendringer blir vanskelig å tolke og at det blir vanskelig å få til en enhetlig praksis. På bakgrunn av de data som nå foreligger for analytisk og biologisk variasjon for troponiner, samt troponinendringer påvist hos pasienter med pågående iskemisk hjertesykdom, valgte derfor arbeids- gruppen å støtte en tilleggsanbefaling fra European Society of Cardiology (4). De foreslår at man hos pasienter med initial troponinkonsentrasjon høyere enn 99-prosentilen definerer en endring på minst $20 \%$ som signifikant. Tilsvarende defineres en endring på minst $50 \%$ som signifikant hos pasienter med initial troponinkonsentrasjon i nivå med 99-prosentilen eller lavere.

Dersom man skal stille infarktdiagnose på bakgrunn av beskrevne endringer $(>20$ / $>50 \%$ ), må man bruke en høysensitiv troponinmetode. Metoder som ved 99-prosentilen har analytisk variasjon (CV) over $20 \%$ eller der 99-prosentilen ikke kan bestemmes pga. dårlig analytisk sensitivitet, bør ikke brukes. Alle som analyserer troponiner, bør delta i eksterne kvalitetskontrollprogrammer og utføre daglig intern kvalitetskontroll.

\section{Konklusjon}

Endringene i tolkingen av troponiner innebærer at flere analyseresultater blir definert

Tabell 1 Arbeidsgruppens anbefaling for diagnostiske beslutningsgrenser for troponin basert på 99-prosentiler (3) for de metodene som er relevante i Norge i 2013

\begin{tabular}{lc} 
Metode & Nivå, ng/l \\
Hs-Troponin T (Roche) & $14^{1}$ \\
Hs-Troponin I (Abbot) & $26^{2}$ \\
STAT Troponin I (Abbot) & 30 \\
Tnl ultra (Siemens) & 40 \\
Troponin I ES (Vitros) & 34 \\
\hline
\end{tabular}

99-prosentil er 9 ng/l for kvinner og 16 ng/l for menn

299 -prosentil er $16 \mathrm{ng} / \mathrm{l}$ for kvinner og $34 \mathrm{ng} / \mathrm{l}$ for menn 
som forenlig med akutt hjerteinfarkt. For å unngå overdiagnostisering er det viktig å innskjerpe krav til klinisk vurdering, inklusive EKG og bildediagnostikk.

\section{Kristin M. Aakre}

kristin.moberg.aakre@helse-bergen.no

Svein Rotevatn

Tor-Arne Hagve

Bjørn Bendz

Sverre Landaas

Thor Trovik

Kristin M. Aakre (f. 1972) er ph.d., spesialist i medisinsk biokjemi, seksjonsoverlege ved Laboratorium for klinisk biokjemi ved Haukeland universitetssykehus og kvalitetskonsulent i Norsk klinisk-kjemisk kvalitetssikring (NKK). Hun har deltatt i Norsk selskap for medisinsk biokjemis arbeidsgruppe for troponiner. Forfatter har fylt ut ICMJE-skjemaet og oppgir ingen interessekonflikter.

Svein Rotevatn (f. 1957) er spesialist i indremedisin og hjertesykdommer, med spesialkompetanse i invasiv kardiologi. Han arbeider ved Hjerteavdelingen, Haukeland universitetssykehus og er faglig leder for Norsk register for invasiv kardiologi.
Forfatter har fylt ut ICMJE-skjemaet og oppgir ingen interessekonflikter.

Tor-Arne Hagve (f. 1953) er dr.med., overlege i medisinsk biokjemi ved Tverrfaglig laboaratoriemedisin og medisinsk biokjemi, Akershus universitetssykehus og professor II ved Institutt for klinisk medisin, Universitetet i Oslo. Han har deltatt i Norsk selskap for medisinsk biokjemis arbeidsgruppe for troponiner.

Forfatter har fylt ut ICMJE-skjemaet og oppgir ingen interessekonflikter.

Bjørn Bendz (f. 1964) er spesialist i indremedisin og kardiologi, arbeider som invasiv kardiolog og er seksjonsleder ved Kardiologisk overvåkning ved Rikshospitalet. Han har deltatt i Norsk Cardiologisk Selskaps arbeidsgruppe for invasiv kardiologi.

Forfatter har fylt ut ICMJE-skjemaet og oppgir ingen interessekonflikter.

Sverre Landaas (f. 1945) er dr.med., spesialist i medisinsk biokjemi og overlege ved Avdeling for medisinsk biokjemi, Oslo universitetssykehus. Han har deltatt i Norsk selskap for medisinsk biokjemis arbeidsgruppe for troponiner. Forfatter har fylt ut ICMJE-skjemaet og oppgir ingen interessekonflikter.
Thor Trovik (f. 1959) er dr.med, spesialist i hjertesykdommer og seksjonsoverlege ved Hjertemedisinsk avdeling, Universitetssykehuset NordNorge. Han er leder for Norsk Cardiologisk Selskaps arbeidsgruppe for invasiv kardiologi. Forfatter har fylt ut ICMJE-skjemaet og oppgir ingen interessekonflikter.

\section{Litteratur}

1. Aakre KM, Landaas S, Hagve TA. Bruk av troponinmålinger i norske sykehus. Tidsskr Nor Legeforen 2010; 130: 278-81.

2. Thygesen K, Alpert JS, Jaffe AS et al. Third universal definition of myocardial infarction. Eur Heart J 2012; 33: 2551-67.

3. Aakre KM, Rotevatn S, Hagve T-A et al. Nasjonale anbefalinger for tolkning av troponinverdier ved diagnostikk av akutt hjerteinfarkt. Tidsskr Nor Legeforen 2013; e-publisert 12.11.2013.

4. Thygesen K, Mair J, Giannitsis E et al. How to use high-sensitivity cardiac troponins in acute cardiac care. Eur Heart J 2012; 33: 2252-7.

Mottatt 18.7. 2013, første revisjon innsendt 26.8. 2013, godkjent 6.10. 2013. Redaktør Trine B. Haugen.

Publisert først på nett. 